\title{
P01.20. The effect of WIN-34B on cartilage protection and regeneration by chondrogenesis from subchondral bone in vitro and in vivo
}

\author{
J Huh*, Y Park, B Seo, Y Baek, J Lee, D Choi, D Park \\ From International Research Congress on Integrative Medicine and Health 2012 \\ Portland, Oregon, USA. 15-18 May 2012
}

\section{Purpose}

WIN-34B is a butanol fraction extract from the mixture of two oriental herbs, the dried Lonicera japonica flowers and the root of Anemarrhena asphodeloides. In previous studies, we indentified that WIN-34B has analgesic, anti-inflammatory, gastroprotective and safety effects. In this study, we measured the major components and investigated the efficacy of WIN-34B on cartilage protection and regeneration through the chondrognesis of mesenchymal progenitor cells of subchondral bone for the treatment of osteoarthritis and development of new medicines.

\section{Methods}

The major chemical composition and quantification of WIN-34B was determined by high performance liquid chromatography. The therapeutic effect of WIN-34B was investigated using a collagenase-induced osteoarthritis (CIA) rabbit model and also by studying chondrogenesis from mesenchymal stem cell of subchondral bone of knee joints.

\section{Results}

In our in vivo study using a CIA rabbit model, oral administration of WIN-34B resulted in siginificant reduction of general clinical and histological scores, associated with a significant inhibition of cartilage loss evaluated by the measurement of the proteoglycan and collagen content. The oral administration of WIN-34B against cartilage destruction had more marked effectiveness than that of the specific COX-2 inhibitor, ETCP, Gluco-Hcl in the CIA rabbit model. Immunohistochemistry analysis of this study showed that oral

Kyung Hee University, Seoul, Republic of Korea

Kyung Hee University, Seoul, Republic of Korea administration of WIN-34B resulted in siginificant increases of CD105 and CD73, typical cell surface antigens known from MSCs. Type II collagen and aggrecan, typical cartilage matrix molecules, were also significantly positive.

\section{Conclusion}

These results suggest that WIN-34B may have shown cartilage protection and cartilage regeneration in a CIA rabbit model through the chondrognesis of mesenchymal progenitor cells of subchondral bone.

Published: 12 June 2012

doi:10.1186/1472-6882-12-S1-P20

Cite this article as: Huh et al:: P01.20. The effect of WIN-34B on

cartilage protection and regeneration by chondrogenesis from

subchondral bone in vitro and in vivo. BMC Complementary and

Alternative Medicine 2012 12(Suppl 1):P20.
Submit your next manuscript to BioMed Central and take full advantage of:

- Convenient online submission

- Thorough peer review

- No space constraints or color figure charges

- Immediate publication on acceptance

- Inclusion in PubMed, CAS, Scopus and Google Scholar

- Research which is freely available for redistribution

C 2012 Huh et al; licensee BioMed Central Ltd. This is an Open Access article distributed under the terms of the Creative Commons Attribution License (http://creativecommons.org/licenses/by/2.0), which permits unrestricted use, distribution, and reproduction in 